\title{
A review of the peacock spiders of the Maratus mungaich species-group (Araneae: Salticidae), with descriptions of four new species
}

\author{
Julianne M. Waldock
}

Department of Terrestrial Zoology, Western Australian Museum, Locked Bag 49, Welshpool DC, Western Australia 6986, Australia.

\begin{abstract}
A newly defined species-group within the jumping spider genus Maratus is identified, based on Maratus mungaich Waldock, 1995 and four new species: M. karrie sp. nov., M. melindae sp. nov., $M$. sarahae sp. nov. and $M$. caeruleus sp. nov. The group is defined by the male colour pattern of alternate transverse stripes on the dorsal abdominal surface and is restricted to south-western Australia.
\end{abstract}

KEYWORDS: taxonomy, morphology, south-western Western Australia

\section{INTRODUCTION}

Since the first recorded observations of these jumping spiders, males of the genus Maratus Karsh, 1878 have elicited fascination for their bright colouration, unusual structural modifications and associated behaviour. As early as 1901 Eugène Simon noted that it is "en Australie que le genre [Saitis] possède les plus nombreuses et les plus belles espèces" ["in Australia the genus [Saitis] has the most numerous and the most beautiful species"] (Simon 1901: 563). In 1987, Żabka removed most of these Australian species from Saitis when he revalidated Maratus and Lycidas Karsch, 1878, and R.A. Dunn first coined the term 'peacock spider' in his description of the mating behaviour of Maratus pavonis (Dunn, 1947) (as Saitis pavonis Dunn, 1947), noting the significance of the colour patterns of iridescent setae on lateral abdominal extensions. However, despite Dunn's observations, it is only in the last 20 years that the striking similarities in the behavior of male Maratus to the mating performances of birds such as peacocks has become fully apparent and well documented (see Waldock 1993; Hill and Otto 2011; Girard et al. 2011; Otto and Hill 2010, 2011, 2012a, 2012b, 2012c, 2013).

Berry et al. (1996) noted that there are currently salticid genera that differ in non-genitalic characters but have genitalia of the same form. This appears to be relevant to the genus Maratus with males having distinctive body forms, colours and colour patterns but very similar pedipalp morphologies. Observations indicate that these somatic features are extremely important for successful courtship performance leading to mating (see Girard et al. 2011). Specialised structures include abdominal flaps, squamous setae that make up the reflective colour patterns and brushes on the legs. These features come together during courtship to create a species-specific morphological signal which is displayed to the female in an elaborate performance that emphasises the different aspects of the displayable suite of features per species.

The purpose of this paper is to define and circumscribe the Maratus mungaich species-group, to provide a new diagnosis for $M$. mungaich Waldock, 1995, and to describe four distinctive new species from south-western Australia, some of which were originally identified as M. mungaich by Waldock (1995).

\section{MATERIALS AND METHODS}

Specimens were preserved and described in $75 \%$ or $100 \%$ ethanol, illuminated with Halogen lights, and illustrated with the abdomen and cephalothorax in a flat, horizontal position. Female genitalia were examined by dissecting epigynes from the abdomen and clearing them in $10 \%$ lactic acid overnight. Epigynes were mounted in glycerol and illustrated with a camera lucida on a Leica DM 2500 compound microscope. Other drawings and measurements were made using a Leica MS 5 or Leica MZ 16A stereo microscope and Leica Application Suite V3.8.0 from Leica Microsystems Ltd.

Material examined for this study is lodged in the Museum of Comparative Zoology, Harvard University, Cambridge, Massachusetts, U.S.A. (MCZ) and the Western Australian Museum, Perth, Australia (WAM). 
TAXONOMY

\section{Family Salticidae Blackwall, 1841}

\section{Subfamily Euophryinae Simon, 1901}

\section{Genus Maratus Karsch, 1878}

Maratus Karsch 1878: 27.

\section{TYPE SPECIES}

Maratus amabilis Karsch, 1878 by subsequent designation of Bonnet (1957: 2713).

\section{COMPOSITION}

Fifteen described species (sensu Żabka 1987) Maratus amabilis Karsch, 1878, M. caeruleus sp. nov., M. calcitrans Otto and Hill, 2012c, M. digitatus Otto and Hill, 2012c, M. harrisi Otto and Hill, 2011, M. karrie sp. nov., M. linnaei Waldock, 2008, M. melindae sp. nov., M. mungaich Waldock, 1985, M. pavonis (Dunn, 1947), M. sarahae sp. nov., M. speciosus (O.P.Cambridge, 1874), M. rainbowi (Roewer, 1951), M. vespertilio (Simon, 1901), M. volans (O.P.-Cambridge, 1874) - and at least 15 undescribed species (Waldock, unpublished data). However, Otto and Hill (2012b) recently synonymised Lycidas Karsch, 1878 (type species L. anomalus Karsch, 1878) with Maratus, greatly expanding the limits of the latter genus and taking the total number of described species to about 40 .

\section{REMARKS}

The specific (and often spectacular) colour patterns on male Maratus species are the result of specialised short squamous setae, which cover the dorsal abdominal scute and parts of the dorsal carapace (e.g. see Otto and Hill 2012a, Figure 5[1]). These setae reflect different colours depending on the angle of orientation and also reflect different colour spectra on different parts of the abdomen.

When preserved in alcohol, the vibrancy of the colours may be reduced, e.g. squamous setae that appear red in life will show as orangey to light brown over time. To standardise the colour pattern descriptions, the specimens were viewed under Halogen lights with the abdomen and cephalothorax in a flat, horizontal position. This combination leads to the squamous setae reflecting colours as rose-gold, orangey, brown and pink. When the abdomen is raised to a vertical position the rose-gold squamous setae reflect as electric blue; in life these rosegold coloured areas are blue-green (see Framenau 2007; Otto and Hill 2011, Figures 13-14, 25-27; Otto and Hill 2012a, Figures 4-13, 17) or purple (see Morcombe 1978, plates on pp. 82-83). To simplify the descriptions the stripes that are red in life (i.e. orangey to light brown in ethanol) are stippled and termed as A, B and C (see Figure 1) and the extensions from these main stripes are called 'arms'.

In a molecular phylogeny of the subfamily Euophryinae, Zhang and Maddison (2013) found that Maratus grouped with several Australian species attributed to Lycidas and Hypoblemum Peckham and Peckham, 1886.

\section{Maratus mungaich species-group}

\section{DIAGNOSIS}

Those species assigned to the newly recognised Maratus mungaich species-group have males with an abdominal colour pattern of red transverse bands on a purple, green or rose-gold background (Figures 1, 3, 5, 12, 20, 25; Otto and Hill 2011, Figures 25-26; Otto and Hill 2012a, Figures 6-7). The abdominal flaps are large and overlap when folded ventrally (Figures 2, 4, 13, 21, 26) and in most species the dorsal red-orange stripes continue onto the abdominal flaps (Otto and Hill 2012a, Figure 7[1]). Also, apart from one of the new species described below (M. caeruleus sp. nov.), species in this group have a small centrally located pale blue spot or line surrounded by a variably-shaped black abdominal patch (Figures 1, 3, 5, 12, 20; Framenau 2007; Otto and Hill 2011, Figure 25[4]; Otto and Hill 2012a, Figure 7).

\section{REMARKS}

Following the publication of the description of Maratus mungaich in 1995, the author became aware of specimens from the Stirling Range that did not match the type series, in particular specimens from Bluff Knoll and Ellen Peak, these being significantly larger than $M$. mungaich (e.g. see Otto and Hill 2012a, Figure 17).

Subsequent to revision of all specimens identified as M. mungaich in the collections of the Western Australian Museum, it is now recognised that there are five species in the M. mungaich species-group in southwestern Western Australia. The recognition of these new species has led to a reassessment of the overall distribution of M. mungaich, indicating that this species has a more restricted distribution than indicated in the original description and the other four species in the Maratus mungaich species-group also have restricted distributions (Figure 30).

\section{KEY TO SPECIES OFTHE MARATUS MUNGAICH SPECIES-GROUP}

Note: Females unknown for M. caeruleus sp. nov. and M. melindae sp. nov.

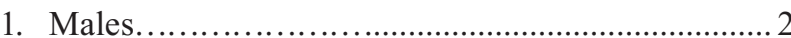

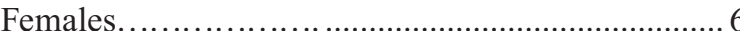

2. Dorsal surface of abdomen with central black patch encircling small light blue spot or line (Figures 1, $3,12,20)$

Dorsal surface of abdomen without central black patch (Figure 25) ........ Maratus caeruleus sp. nov.

3. Abdominal flaps with black median 'eye' (Figures 2, $4,13)$ 4 
Abdominal flaps without black median 'eye' (Figure 21)... Maratus melindae sp. nov.

4. Leg III with distal brush only on tibia, metatarsus and tarsus (Figure 16; see also Otto and Hill 2012a, Figure 9[3]).

Leg III with all segments bearing long white hairs (Figure 8; see also Otto and Hill 2012a, Figure $9[2])$ Maratus sarahae sp. nov.

5. Abdominal flaps with large black median 'eye' isolated and not surrounded by extension of stripe B (Figure 13; see also Otto and Hill 2012a, Figure $18[2])$ Maratus karrie sp. nov.

Abdominal flaps with small black median 'eye' almost encircled by red lateral extension of stripe B (Figure 2; see also Otto and Hill 2012a, Figures $8[7]-8[12])$ Maratus mungaich Waldock

6. Epigyne with proximal receivers overlapping across median guide (Figure 18); dorsal abdomen with dark grey patches over entire surface (Figure 17) .. Maratus karrie sp. nov.

Epigyne with proximal receivers not overlapping across median guide (Figure 10).

7. Proximal receivers of epigyne long, extending across spermatheca (see Waldock 1995, Figure 8); dorsal abdomen with faint dark greyish patches on creamy background (see Waldock 1995, Figure 7) Maratus mungaich Waldock
Proximal receivers of epigyne short, not extending laterally (Figure 10); dorsal surface of abdomen with foliate pattern of dark grey patches on creamy background (Figure 9)

Maratus sarahae sp. nov.

\section{Maratus mungaich Waldock, 1995}

\section{Banksia Peacock Spider}

Figures $1-2,30$

Maratus mungaich Waldock 1995: 165, Figures 1-9; Hill 2009: 11; Hill 2010: 50; Prószyński 2005; Otto and Hill 2011: 12, Figures 13-14; Otto and Hill 2012a: 8, Figures 7(3)-7(4), 8(7)-8(12), 9(3), 11, 13, 15(7)-15(12), 16(3)-16(4), 17; Platnick 2013.

\section{MATERIAL EXAMINED}

\section{Holotype}

Australia: Western Australia: đ', Mt Cooke, $32^{\circ} 25^{\prime}$ S, $116^{\circ} 18^{\prime}$ E, 1 October 1990, M.S. Harvey, J.M. Waldock (WAM 93/1635).

\section{Paratypes}

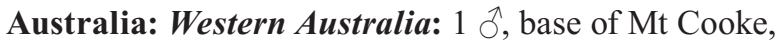
jarrah-marri forest, $32^{\circ} 25^{\prime} \mathrm{S}, 1^{116^{\circ} 18^{\prime} \mathrm{E}, 29}$ September 1990, J.M. Waldock (WAM 93/1628); 6 §, 1 क, Mt Cooke, $32^{\circ} 25^{\prime}$ S, $116^{\circ} 18^{\prime} \mathrm{E}, 1$ October 1990, M.S. Harvey, J.M. Waldock (WAM 93/1629-34; 93/2091); 3 ô, same data as holotype except 19 September 1991, M.S.
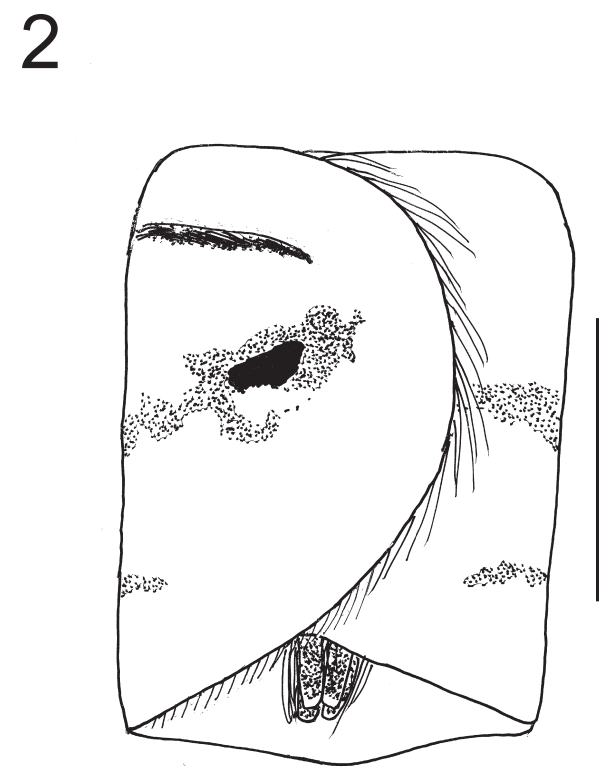

FIGURES 1-2 Maratus mungaich Waldock, 1995, male holotype (WAM 93/1635): 1, abdomen, dorsal view; 2, abdomen, ventral (abdominal flaps folded). Scale lines $=1 \mathrm{~mm} . \mathrm{A} / \mathrm{B} / \mathrm{C}=$ red transverse stripes $\mathrm{A}-\mathrm{C}$. 
Harvey, J.M. Waldock (WAM 93/1636-8); 1 ふ, same data as holotype except 12 October 1991, J.M. Waldock (WAM 93/1639); 3 ふै, 1 q, same data as holotype except 13 October 1991, J.M. Waldock (WAM 93/1640-3).

\section{Additional material}

Australia: Western Australia: 1 , Avon National Park, junction of Sapper and Plunkett Roads, 31 34'41.8'S, 11609'52.7''E, 14 July 2012, J.M. Waldock, K. Brimmell, G.B. Hughes (WAM T127622); 2 ô, Cardup Reserve, site CR 3, 32॰14'53”S, 115'59'08'E, 16 April-17 June 1996, wet pitfalls, J.M. Waldock, P. West, A. Longbottom (WAM T55816); 1 $\hat{\jmath}$, NE. of Jarrahdale, Alcoa minesite [32 $17^{\prime}$ S, $\left.116^{\circ} 08^{\prime} \mathrm{E}\right]$, October 1997, wet pitfalls, K.E.C. Brennan (WAM T48323); 1 $\hat{\text {, }}$, same data (WAM T49301); 1 ㅇ, same data except April 1998, K.E.C. Brennan, L. Ashby (WAM T49302); 1 q [epigyne missing], same data except April 1999, M.L. Moir (WAM T48324); 1 今, Jarrahdale (Alcoa) mine area, 32¹6’S, $116^{\circ} 06^{\prime} \mathrm{E}$, November 2001, M.L. Moir \#62, suction sample ex Dryandra lindleyana (WAM T55758); 1 ô, same data except \#61, tree beat sample ex Xanthorrhoea preissii (WAM T55759); 1 ○े, same data except \#65, suction sample ex Lasiopetalum floribundum (WAM T55757); 1 , Julimar Road, $30 \mathrm{~km} \mathrm{W.} \mathrm{of} \mathrm{Toodyay,} \mathrm{running} \mathrm{in}$ litter, jarrah forest [ $\left.31^{\circ} 31^{\prime} \mathrm{S}, 116^{\circ} 03^{\prime} \mathrm{E}\right], 28$ September 1986, J.M. Waldock (WAM T47103); 6 ô, 1 \%, Mt Cooke, site 1, pitfall traps, $32^{\circ} 25^{\prime} \mathrm{S}, 116^{\circ} 18^{\prime} \mathrm{E}, 19$ September-28 November 1991, J.M. Waldock, C.A. Car (WAM 97/2569-5); 1 §o, Mt Cooke, base, 32 ${ }^{\circ} 25^{\prime} \mathrm{S}, 116^{\circ} 18^{\prime} \mathrm{E}, 24$ October 1999, J.M. Waldock (WAM T46948); 1 , c. 2 $\mathrm{km} \mathrm{N}$. of Mt Dale, jarrah forest, $32^{\circ} 08^{\prime} \mathrm{S}, 116^{\circ} 18^{\prime} \mathrm{E}, 5$ October 1992, J.M. Waldock (WAM T47104); 2 ふै, W. side of Mt Dale, running in leaf litter, $32^{\circ} 07^{\prime} \mathrm{S}, 116^{\circ} 18^{\prime} \mathrm{E}$, 29 September 1997, K. Brimmell, J.M. Waldock (WAM T47105); 1 $\delta$, base of northern slope of Mt Dale, banksia woodland, 3208'S, 116 $18^{\circ} \mathrm{E}, 26$ September 1998, B. Slack-Smith, J.M. Waldock (WAM T47106); 6 ふ઼, 3 ㅇ, base of Mt Dale, W. side, $32^{\circ} 08^{\prime}$ S, $116^{\circ} 18^{\prime} \mathrm{E}, 26$ September 1998, J.M. Waldock et al. (WAM T55822-30); 1 ๙̃., NW. of Mt Dale, site RL1, 32 05 '39"S, $116^{\circ} 16^{\prime} 49^{\prime \prime} \mathrm{E}, 15-30$ August 2001, A. Watson, wet pitfall traps, recently logged jarrah forest (WAM T55831); $1 \hat{0}$, same data except site RL2, 3205'19'S, 116 16 '52'E (WAM T55832); 3 ô, same data except site RL3, 32 $02^{\prime} 57^{\prime}$ 'S, $116^{\circ} 17^{\prime} 06^{\prime \prime} \mathrm{E}$ (WAM T55833-5); 2 ${ }^{\lambda}, 1$ ㅇ, same data except site RLB2, $32^{\circ} 06^{\prime} 14^{\prime \prime} \mathrm{S}, 116^{\circ} 16^{\prime} 36^{\prime \prime} \mathrm{E}$, recently logged and burnt jarrah forest (WAM T55836); $1 \hat{\jmath}$, same data except site RLB4, $32^{\circ} 06^{\prime} 07^{\prime}$ 'S, $116^{\circ} 16^{\prime} 18^{\prime \prime} \mathrm{E}$, recently logged and burnt jarrah forest (WAM T55837); 2 $\hat{\alpha}$, same data except site LL2, 32 $05^{\prime} 30^{\prime \prime} \mathrm{S}, 116^{\circ} 16^{\prime} 40^{\prime \prime} \mathrm{E}$, long-logged ( $>50$ years ago) jarrah forest (WAM T55838); $1 \hat{\jmath}$, same data except site LL4, 32 05 '16'S, $116^{\circ} 16$ '42”E, long-logged (> 50 years ago) jarrah forest (WAM T55839); 1 $\sigma^{\lambda}$, same data except site LL5, 32 $05^{\prime} 00^{\prime}$ 'S, $116^{\circ} 16^{\prime} 59^{\prime}$ 'E, long-logged ( $>50$ years ago) jarrah forest (WAM T55850); $1 \hat{\jmath}, 1$ q, same data except site OG1, 32 $02^{\circ} 33^{\prime \prime} \mathrm{S}, 116^{\circ} 17^{\prime} 42^{\prime \prime} \mathrm{E}$, old growth jarrah forest (WAM T55840); 2 o, same data except site OG4, $32^{\circ} 06^{\prime} 04^{\prime \prime} \mathrm{S}, 116^{\circ} 17^{\prime} 15^{\prime \prime} \mathrm{E}$, old growth jarrah forest (WAM T55841, T55849); 1 $\hat{O}, 1$, same data except site OGB1, 3207'10"S, 116 $17^{\circ} 28^{\prime}$ 'E, old growth burnt jarrah forest (WAM T55842-3); $1 \hat{\jmath}$, same data except site OGB2, 32 $07^{\prime} 19^{\prime \prime} \mathrm{S}, 116^{\circ} 17^{\prime} 33^{\prime \prime} \mathrm{E}$, old

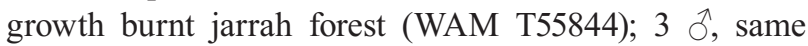
data except site OGB3, 32 $06^{\prime} 26^{\prime}$ 'S, $116^{\circ} 17^{\prime} 05^{\prime}$ 'E, old growth burnt jarrah forest (WAM T55845-6); 2 ${ }^{\lambda}$, same data except site OGB4, 32 $07^{\prime} 25^{\prime}$ 'S, $116^{\circ} 17^{\prime} 36^{\prime \prime} \mathrm{E}$, old growth burnt jarrah forest (WAM T55847-8); 1 o, Mt Dale, off Omeo Road, near Bibbulmun Track, 32 07'27'S, 116 17'22'E, 12 September 2010, D. Harms, S. Harms, M. Rix, M. Mathew, J. Waldock, K. Brimmell (WAM

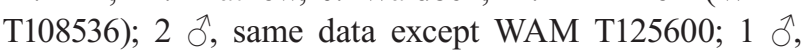
SSW. of Mt Observation, near headwaters of Helena River, c. $31^{\circ} 57^{\prime} \mathrm{S}, 116^{\circ} 38^{\prime} \mathrm{E}, 1$ October 1995 , J.M. Waldock, wandoo woodland (WAM 95/776); 1 ō, Omeo Road, near Brookton Highway, gravel pit, 32 11 '56”S, $116^{\circ} 17^{\prime} 15^{\prime \prime} \mathrm{E}$, 27 September 2003, J.M. Waldock (WAM T55959).

\section{DIAGNOSIS}

Males of Maratus mungaich can be distinguished from all other species in the $M$. mungaich species-group except $M$. karrie sp. nov. and $M$. sarahae sp. nov. by the presence of a median black 'eye' patch on each abdominal flap (Figure 2); from $M$. sarahae sp. nov. by the much smaller body size (see Otto and Hill 2012a, Figure 17) and the absence of setal brushes on the leg III femora (see Otto and Hill 2012a, Figure 9[3]; and from M. karrie sp. nov. by the larger abdominal flaps (Figure 2) and the smaller black median 'eye' patches which are almost completely encircled by the red lateral extensions of stripe arm 'B' (Figure 2; see also Otto and Hill 2012a, Figures 8[7]$8[12])$

\section{DESCRIPTION}

\section{Male (holotype)}

See Waldock (1995). For qualification, note that red stripe arm B continues onto lateral flaps and almost encircles small black patch, with light blue squamous setae on posterior gap of red stripe B (Figure 2).

\section{Female (WAM 93/2091)}

See Waldock (1995). For qualification, note that epigyne with openings of insemination ducts along lower lateral border of fossae.

\section{DISTRIBUTION}

Following re-assessment of specimens originally identified as M. mungaich (see Waldock 1995) and additional material collected more recently, M. mungaich is now known to be quite restricted and found to occur in bushland around the Perth metropolitan region, extending north to Toodyay, south to Mt Cooke, and east to Darkin Road (Figure 30).

\section{REMARKS}

Recent photographic studies of live male specimens of Maratus mungaich by J. Otto and others (Otto and Hill 2011, Figures 13-14; Otto and Hill 2012a, Figures 
$7(3)-7(4), 8(7)-8(12), 9(3), 11,13)$ have indicated that the original description of $M$. mungaich by Waldock (1995) overlooked a significant feature on the abdominal flaps of males, i.e. the presence of a small black patch on the flaps of M. mungaich sens. str. This patch is situated centrally on the flap, almost completely surrounded by the central red stripe arm B that extends from the dorsum. This small black patch is found on all specimens checked for the present study, although the patch is difficult to observe on many older specimens which usually need to be suitably angled to the light. Upon reassessment of the collections of $M$. mungaich several specimens were observed with slight variations in the male colour pattern relative to the type material. For example, not all specimens have diagonal posteriorly-directed arms from stripe A, with some reduced to simple bumps, and the anterior border of stripe A also varies from having a deep incision centrally (Figure 1) to only a slight depression.

\section{Maratus sarahae sp. nov.}

urn:Isid:zoobank.org:act:F31D47FC-AE28-4B71-9192257A95DC40F6

\section{Sarah's Peacock Spider}

Figures 3-11, 30

'Maratus sp.': Hill and Otto 2011: 39 (figure from V.W. Framenau [but not the images of MCZ 101302, p. 39]).

'Maratus sp. A' (in part): Otto and Hill 2011: 20, Figures 25-27; Otto and Hill 2012a: 1, Figures 3- 6, 7(1)-7(2), 8(1)-8(6), 9(1)-9(2), 10, 12, 14, 15(1)-15(6), 16(1)-16(2), 17 [but not Darlington's specimens referenced and imaged on p. 19, Figure 18].

\section{MATERIAL EXAMINED}

\section{Holotype}

Australia: Western Australia: ふ̄, Bluff Knoll, Stirling Range National Park, site 10, 34²2'51''S, $118^{\circ} 18^{\prime} 02^{\prime}$ E, 12 November 2007, M.L. Moir (WAM T125614).

\section{Paratypes}

Australia: Western Australia: 1 , same data as holotype (WAM T125615); 1 $\delta, 2$ o, same data as holotype (WAM T99864); 2 ô, 1 ㅇ, same data as holotype except $34^{\circ} 23^{\prime} \mathrm{S}, 118^{\circ} 15^{\prime} \mathrm{E}, 29$ November 1988 , D. Knowles (WAM 93/1619-21) [misidentified as $M$. mungaich by Waldock (1995)].

\section{Other material}

Australia: Western Australia: 2 juveniles, Bluff Knoll, Stirling Range National Park, 342'ㅇ, $118^{\circ} 15^{\prime} \mathrm{E}$, 29 November 1988, D. Knowles (WAM 93/1622-3); 1 $\hat{\jmath}$, Ellen Peak, Stirling Range National Park, saddle, 1000 m, 34²1'32”S, 118¹9'46”E, 4 April 1995, S. Barrett (WAM 97/2594); 1 ऽ̄, Ellen Peak, Stirling Range National Park, 34²2’S, $118^{\circ} 20^{\prime}$ E, 21 September 1995, S.
Barrett (WAM 97/2595); 1 ô, Ellen Peak, Stirling Range National Park, $1007 \mathrm{~m}$, beating/sifting low vegetation and leaf litter, 34²1'30'S, 118 $19^{\circ} 57^{\prime}$ 'E, 6 November 2007, M.G. Rix et al. (WAM T99765); 1 ふૈ, Ellen Peak, Stirling Range National Park, 995 m, beating reeds, 34²1'29”S, 118 19'54”'E, 30 November 2007, M.L. Moir (WAM T99366).

\section{DIAGNOSIS}

Maratus sarahae can be distinguished from all other species in the $M$. mungaich species-group except $M$. karrie sp. nov. and $M$. mungaich by the presence of a median black 'eye' patch on each abdominal flap (Figure 4); and from M. karrie sp. nov. and M. mungaich by the much larger body size (e.g. see Otto and Hill 2012a, Figure 17) and the presence of setal brushes on the leg III femora (Figure 8; see also Otto and Hill 2012a, Figure 9[2]).

\section{DESCRIPTION}

\section{Male (holotype)}

Cephalothorax black to dark brown with white hairs bordering lateral edges. Dense mat of light orange squamous setae covering ocular region. Anterior eyes fringed with creamy hairs along dorsal margin; rest of cephalothorax lightly covered with scattered short white hairs and brown bristles (Figure 3). Clypeus orangeybrown, chelicerae dark brown, yellow distally. Maxillae creamy-yellow, labium dark brown with cream edge. Sternum dark brown.

Venter of abdomen dark yellow with greyish smudges in centre and laterally; spinnerets black. Dorsal abdominal scute developed as lateral flaps which fold over each other ventrally, but extendable laterally to exhibit a continuation of dorsal pattern (these flaps partially extended in holotype specimen; Figure 5). Stripe A of red-orange squamous setae present, merging with broad anterior black patch medially (Fig $3,5)$. Stripe B of red-orange narrow, merging with lower extensions of central black patch (Figures 3, 4, 5) and extending onto flaps as reddish spots. Central black patch with four 'arms' extending laterally with small light blue elongate strip in centre (Figures 3, 5). Stripe $\mathrm{C}$ thin of red-orange squamous setae laterally, extending onto flaps, forming black stripe across dorsum; second thin black stripe anterior to stripe $\mathrm{C}$ (Figure 3). Anterior corners of abdomen with stiff orange and black bristles. Stiff long cream and brown bristles projecting from anterior border of abdomen (Figures 4, 5). Lateral flaps with large black circular 'eye' patch anteriorly; 'eye' patch almost entirely encircled with red-orange anteriorly, remainder of flaps rose-gold and bright blue except for small patches of red at fold with dorsum as extensions from stripes A, B and C. Long creamy hairs bordering edges of flaps (Figure 4). Legs with brushes of thick white hairs on ventral surfaces of all segments. Legs I, II and IV: femora, patellae and tibiae yellowish-grey dorso-anteriorly with dark grey patches 

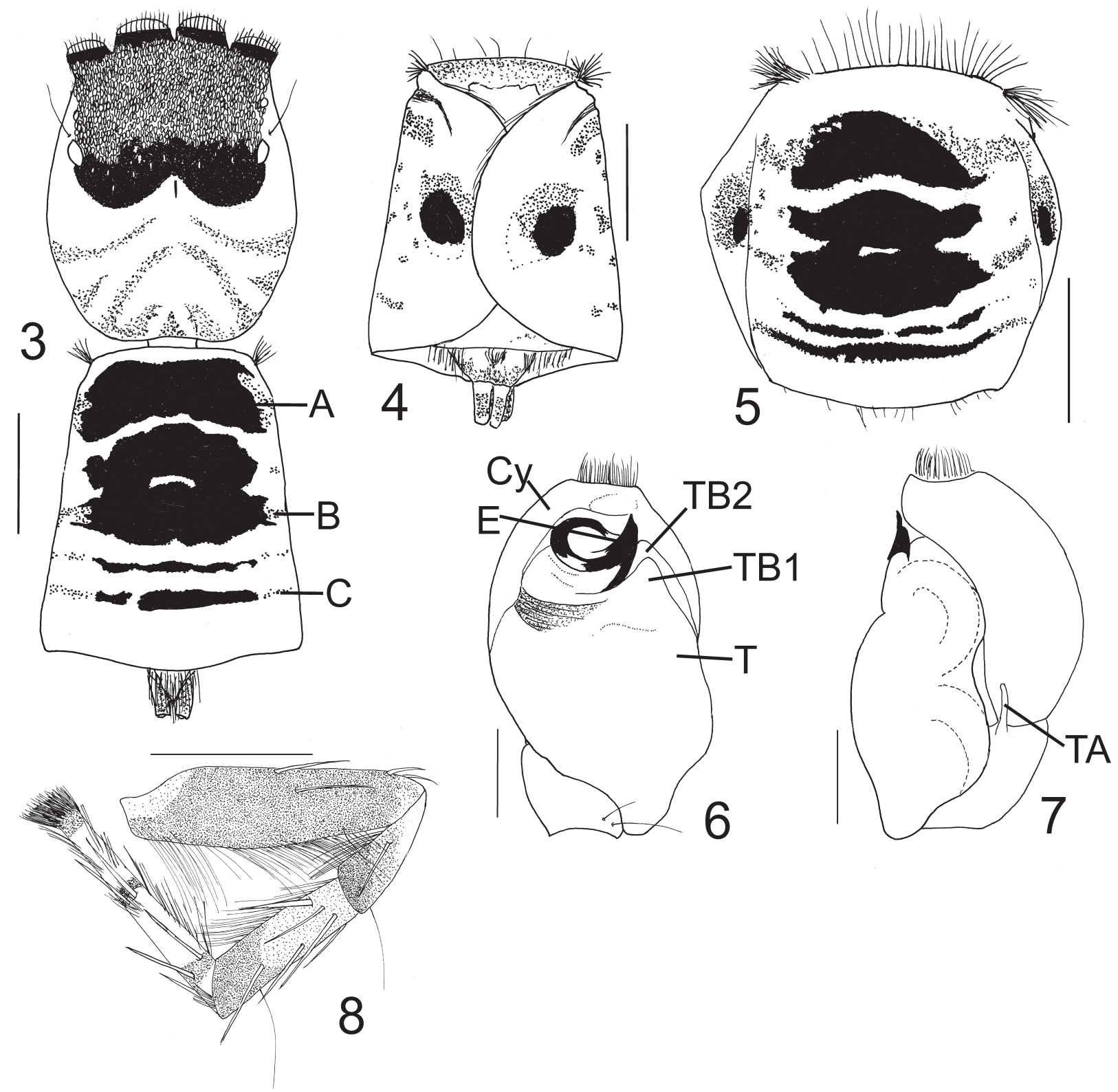

FIGURES 3-8 Maratus sarahae sp. nov., male holotype (WAM T125614) from Bluff Knoll, WAM T99765 and 97/2595 from Ellen Peak: 3, cephalothorax and abdomen, dorsal view (WAM T99765); 4, abdomen, ventral view (abdominal flaps folded) (WAM T99765); 5, abdomen, dorsal view (flaps partially unfolded) (WAM T125614); 6, left pedipalp (of WAM 97/2595), ventral view; 7, left pedipalp (of WAM 97/2595), retrolateral view; 8, left leg III, retrolateral view (WAMT125614). Scale lines $=1 \mathrm{~mm}$ (Figures 3-5, 8), $0.5 \mathrm{~mm}$ (Figures $6-7$ ). $A / B / C=$ red transverse stripes $A-C ; C y=$ cymbium; $E=$ embolus; $T=$ tegulum; $T A=$ tibial apophysis; TB1-2 = tegular bulges 1-2.

ventro-posteriorly; metatarsi and tarsi yellow; covered with dense short white hairs interspersed with black bristles. Leg III: femur, patella and tibia dark grey, metatarsus yellow with grey patches, tarsus cream; tibia and metatarsus with shorter white hairs retrolaterally; tarsus with thick short white hairs on all surfaces and thick brush of dark grey hairs at tip, covering claws (Figure 8).

Pedipalp yellow with scattered greyish patches distally. Tibial apophysis narrow, straight (Figure 6). Cymbium, dorsal tibia and dorsal patella densely covered with long white hairs, a single very long black hair on dorsal pedipalpal patella, tibia and cymbium with a few long creamy hairs on ventral side just under tegulum. Embolus with broad tip and conductor closely aligned with embolus into tight coil, tucked under tip of cymbium; tegulum with two bulges adjacent to embolus (Figure 6).

\section{Female (paratype, WAM T125615)}

Ocular region black, densely covered with short black and creamy hairs, rest of cephalothorax tan grading 

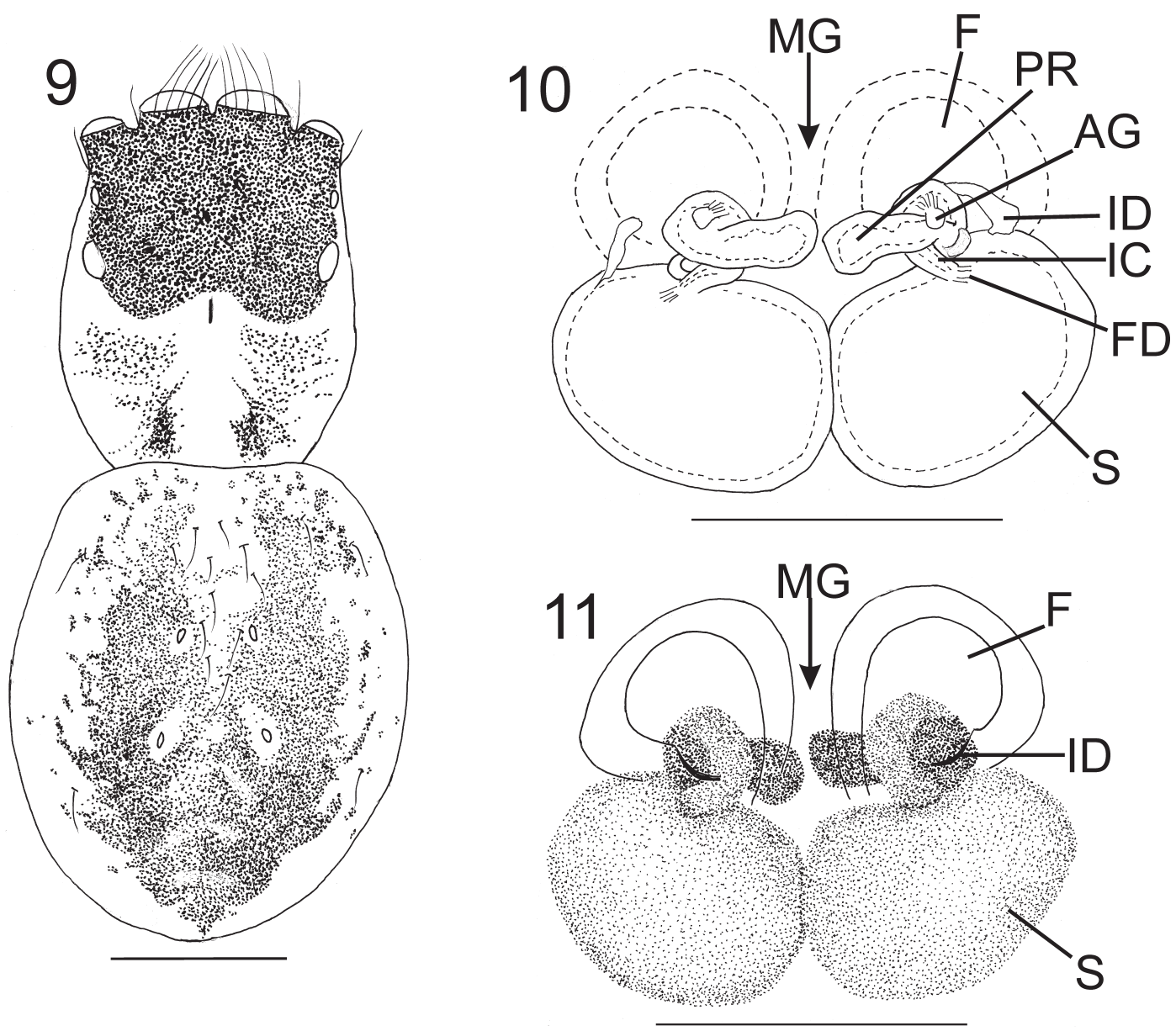

FIGURES 9-11 Maratus sarahae sp. nov., female paratype (WAM T125615): 9, cephalothorax and abdomen, dorsal view; 10, cleared epigyne, dorsal view; 11, epigyne, ventral view. Scale lines = $1 \mathrm{~mm}$ (Figure 9), 0.25 $\mathrm{mm}$ (Figures 10-11). $A G=$ accessory gland; $F=$ fossa; $F D=$ fertilisation duct; IC = intermediate canal; ID = insemination duct; $\mathrm{MG}=$ median guide; $\mathrm{PR}=$ proximal receiver; $\mathrm{S}=$ spermatheca.

to yellow towards posterior with scattered black hairs. Broad light yellow central band extending from fovea to posterior margin of abdomen, with some white hairs still evident within this band. Sides of cephalothorax creamy yellow. Clypeus creamy; chelicerae, maxillae, labium yellow with white border. Sternum cream to pale yellow.

Abdomen oval with greyish dorsal sigillae and black bristles scattered amongst brown and creamy hairs; most of dorsum covered in greyish foliate pattern on creamy background; pattern darkens towards posterior (Figure 9). Venter of abdomen cream, with small grey spots in longitudinal rows, larger spots at edges. Spinnerets grey.

Femora and patellae of legs creamy, no markings dorsally, grey patches at joints and mid-way of femora; tibiae, metatarsi and tarsi yellowy with grey bands at joints.

Proximal receivers of epigyne separated across median guide. Intermediate canals very short, opening directly into central anterior portion of spermathecae. Insemination ducts opening centrally above anterior portion of spermathecae (Figures 10, 11).

\section{Dimensions ( $\mathrm{mm})$}

Holotype $\widehat{\delta}$ (paratype $\bigcirc$, WAM T125615): total length (excluding chelicerae) 7.40 (7.54). Carapace length 3.62 (3.26). Abdomen length 3.58 (4.12). Leg I: femur 1.88 (1.59), patella $1.24(0.99)$, tibia $1.20(0.95)$, metatarsus 0.93 (0.49), tarsus 0.65 (0.69). Leg II: femur 1.71 (1.37), patella $1.02(0.80)$, tibia $0.93(0.85)$, metatarsus 0.88 (0.77), tarsus 0.63 (0.52). Leg III: femur 2.59 (2.11), patella $1.29(1.05)$, tibia $1.68(1.25)$, metatarsus 1.68 (1.23), tarsus 1.15 (0.82). Leg IV: femur 3.02 (1.88), patella 1.04 (1.01), tibia 1.34 (1.15), metatarsus 1.37 (1.36), tarsus $0.86(0.74)$. Legs, relative lengths: III: IV: I: II (III: IV: I: II).

\section{DISTRIBUTION}

Maratus sarahae appears to be restricted to the higher peaks of the eastern Stirling Range, and is currently known only from Bluff Knoll and Ellen Peak (Figure 30). This is not a unique distribution, however, as there are several other arachnids that also reflect this pattern, for example the spiders Calcarsynotaxus benrobertsi 
Rix, Roberts and Harvey, 2009 (Synotaxidae) (see Rix et al. 2009), Zephyrarchaea robinsi (Harvey, 2002) (Archaeidae) (see Rix and Harvey 2012) and Perissopmeros darwini Rix, Roberts and Harvey, 2009 (Malkaridae) (see Rix et al. 2009), and the harvestman Megalopsalis epizephyros Taylor, 2011 (Phalangioidea) (see Taylor 2011). These species show such small and restricted distributions that they are clearly short-range endemics as defined by Harvey (2002).

\section{REMARKS}

Although Hill and Otto (2011: 39) and Otto and Hill (2012a: 19) identified a single new species of Maratus from specimens collected at Bluff Knoll, Margaret River and Pemberton (i.e. their 'Maratus sp. A'), there are at least two different species here recognised under the 'Maratus sp. A' concept of Hill and Otto (2011) and Otto and Hill (2012a). The specimens from Bluff Knoll are here identified as M. sarahae and the specimens from Margaret River and Pemberton as M. karrie sp. nov. Hill and Otto (2011) and Otto and Hill (2012a) also refer to a figure from Żabka (1991) as 'Maratus sp. A' but the locality given for this image is simply "Western Australia" so it is not possible to assign a species name to this image.

\section{ETYMOLOGY}

The specific epithet is a patronym in honour of Sarah Comer, Regional Ecologist for the South Coastal Region of the Department of Environment and Conservation, who has consistently collected innumerable invertebrates from often remote and difficult corners of the southwestern regions of Western Australia.

\section{Maratus karrie sp. nov.}

\section{urn:Isid:zoobank.org:act:E8763E3A-575E-457E-} A780-8E3240F0ACC9

\section{Karri Peacock Spider}

Figures 12-19, 30

Maratus mungaich Waldock 1995 (in part): 167 (misidentification of specimens from Crowea and Manjimup).

'Maratus sp.' (in part): Hill and Otto 2011: 39 (reference to Darlington's specimens and Figures of MCZ 101302 [but not image from V.W. Framenau]).

'Maratus sp. A' (in part): Otto and Hill 2011: 20 (reference to Darlington' specimens); Otto and Hill 2012a: 19, Figure 18.

\section{MATERIAL EXAMINED}

\section{Holotype}

Australia: Western Australia: $\hat{\partial}$, Mt Frankland National Park, Mt Roe, site 1, sandy track, 3442'21'’S, $116^{\circ} 48^{\prime} 02^{\prime}$ 'E, 28 October 2006, M.L. Moir, A. Sampey
(WAM T78898).

\section{Paratype}

Australia: Western Australia: 1 , same data as holotype (WAM T125616).

\section{Other material}

Australia: Western Australia: 1 $\hat{\text {, }}$, Crowea Forest, $34^{\circ} 28^{\prime} \mathrm{S}, 116^{\circ} 10^{\prime} \mathrm{E}$, ridge site, area $\mathrm{A}$, open forest (regrowth), 8 November 1979, S. J. Curry (WAM 93/1649) [misidentified as M. mungaich by Waldock (1995)]; 2 ô, Manjimup [34 $\left.15^{\prime} \mathrm{S}, 116^{\circ} 09^{\prime} \mathrm{E}\right], 30$ November 1926 , L. Cheney (WAM 26/801-802) [misidentified as $M$. mungaich by Waldock (1995)]; 1 ô, Margaret River

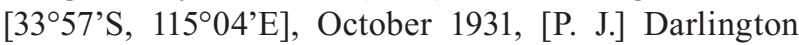

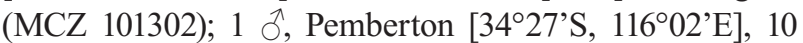
November 1931, [P. J.] Darlington (MCZ 101295).

\section{DIAGNOSIS}

Maratus karrie can be distinguished from all other species in the M. mungaich species-group except $M$. mungaich and $M$. sarahae by the presence of a median black 'eye' patch on each abdominal flap (Figure 13); from $M$. sarahae by the much smaller body size and absence of setal brushes on the leg III femora (Figure 16); and from M. mungaich by the lack of extension of stripe B from the dorsum to the 'eye' patch (Figure 13) and the larger black median 'eye' patches which are isolated, each with small patch of red only along anterior edge (Figure 13; see also Otto and Hill 2012a, Figure $18[2])$.

\section{DESCRIPTION}

\section{Male (holotype)}

Cephalothorax black to dark brown with white hairs bordering lateral edges. Dense mat of creamy flat hairs covering ocular region. Anterior eyes fringed with creamy-orange hairs along dorsal margin; rest of cephalothorax lightly covered with scattered short white hairs, including small patch posterior to fovea (Figure 12). Clypeus yellow; chelicerae dark brown. Maxillae, labium light cream. Sternum dark brown.

Venter of abdomen pale yellow with greyish smudges; anterior spinnerets light cream with black tips, posterior ones, black. Dorsal abdominal scute developed as lateral flaps which fold over each other ventrally, but extendable laterally to exhibit a continuation of dorsal pattern. Abdominal pattern consisting of alternating narrow transverse stripes $\mathrm{A}, \mathrm{B}$ and $\mathrm{C}$ of red-orange and wider blue/rose-gold bands. Abdomen with a square-shaped matte black patch medially, surrounding small light blue crescent-shaped strip in centre. A second, smaller black patch situated medially within red stripe A. Stripe $\mathrm{C}$ of red-orange squamous setae laterally, medially black; additional thin strip of black squamous setae in centre, anterior to stripe $\mathrm{C}$ (Figure 12). Anterior corners of abdomen with stiff dark brown and black bristles. Stiff brown bristles projecting from anterior border of abdomen (Figure 12). Lateral flaps rose-gold to bright 
blue, each with a large black circular 'eye' patch (Figure 13); anterior border of each 'eye' patch encircled with a thin margin of bright orange, posteriorly with small patch of light blue. Red-orange stripe B on dorsum aligns with 'eye' but dissipates laterally and does not extend to 'eye' on flap. Flaps with long creamy hairs bordering edges (Figure13).
Legs covered with dense short white hairs interspersed with black bristles. Dorsal femora creamy yellow with greyish-black patches distally that merge with retrolateral patches. Dorsal patellae light yellow with dark grey patches ventrally; tibiae and metatarsi of legs I, II and IV creamy-yellow with dark grey bands proximally on each joint. Tarsi of all legs creamy-yellow; tarsi III

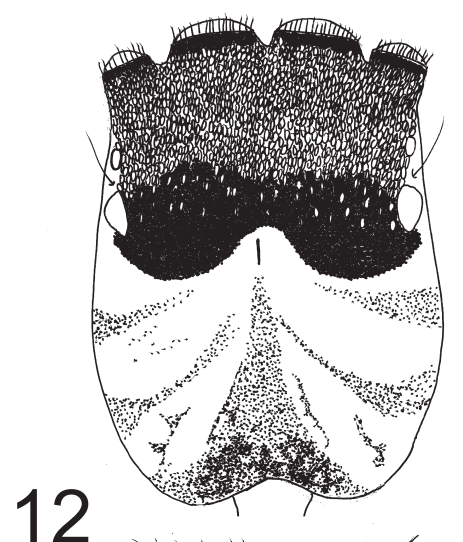

12
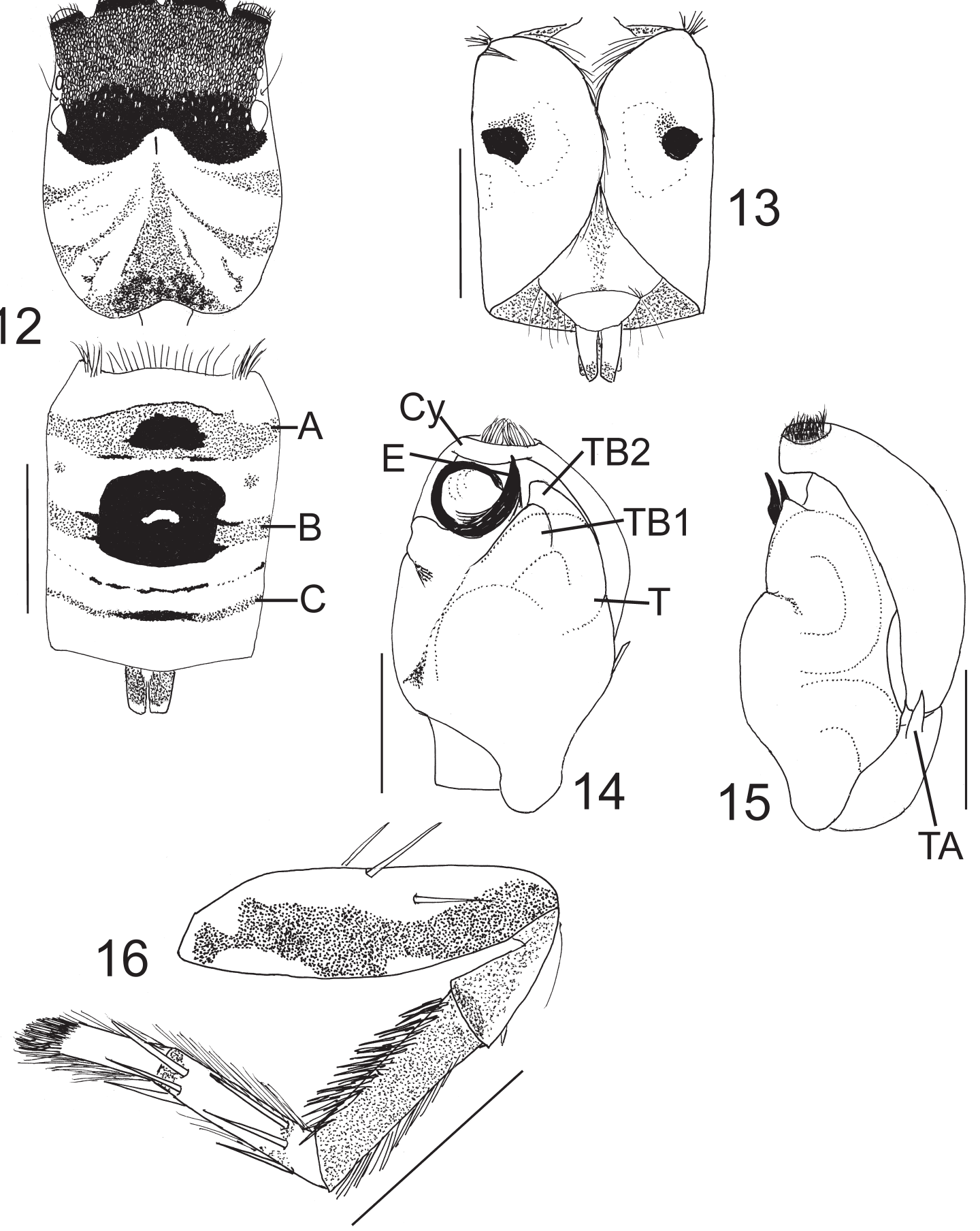

FIGURES 12-16 Maratus karrie sp. nov., male holotype (WAM T78898): 12, cephalothorax and abdomen, dorsal view; 13, abdomen, ventral view (abdominal flaps folded); 14, left pedipalp, ventral view; 15, left pedipalp, retrolateral view; 16, left leg III, retrolateral view. Scale lines $=1 \mathrm{~mm}$ (Figures 12-13, 16), $0.5 \mathrm{~mm}$ (Figures 14-15). $A / B / C=$ red transverse stripes $A-C ; C y=$ cymbium; $E=$ embolus; $T$ = tegulum; $T A=$ tibial apophysis; TB1-2 = tegular bulges 1-2. 

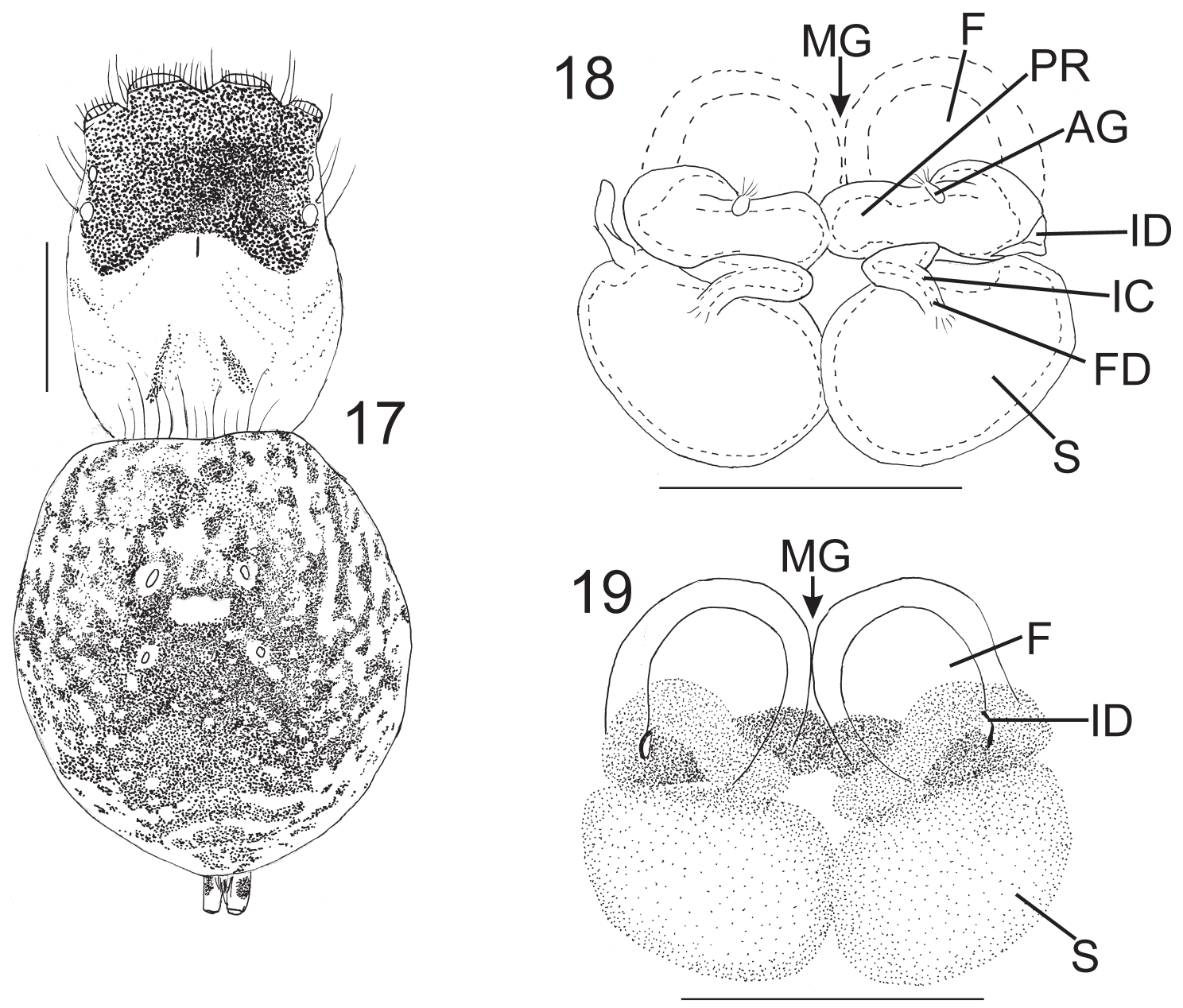

FIGURES 17-19 Maratus karrie sp. nov., female paratype (WAM T125616): 17, cephalothorax and abdomen, dorsal view; 18, cleared epigyne, dorsal view; 19, epigyne, ventral view. Scale lines $=1 \mathrm{~mm}$ (Figure 17), $0.25 \mathrm{~mm}$ (Figures 18-19). $A G$ = accessory gland; $F=$ fossa; FD = fertilisation duct; IC = intermediate canal; ID = insemination duct; $M G=$ median guide; $P R=$ proximal receiver; $S=$ spermatheca.

and IV with dark grey tips. Tibia of leg III dark grey on yellow; metatarsus III creamy-yellow with dark grey bands proximally and distally. Leg III with brush of black bristles and thick hairs ventrally on patella and tibia; rest of tibia III covered with thin black bristles; brush of thick white hairs on ventral metatarsus and entire tarsus, this brush especially dense on dorsal surface of tarsus, extending over tips of claws (Figure 16).

Pedipalp light cream with scattered light grey patches. Tibial apophysis narrow, straight except for a slight distal curve (Figure 15). Cymbium, dorsal tibia and dorsal patella densely covered with long white hairs, a single long light brown hair on dorsal pedipalpal patella; two long cream-coloured hairs on tibia as well as a few thicker brown bristles on external ventral side just under tegulum. Embolus with conductor closely aligned into tight coil, tucked under tip of cymbium; tegulum with two bulges adjacent to embolus (Figure 14).

\section{Female (paratype, WAM T125616)}

Ocular region black with dense covering of short white hairs, interspersed with short black hairs, rest of cephalothorax yellow with light tan patches grading to yellow laterally and brown patch behind ocular area extending towards posterior edge. A central yellow area divides this posterior patch. Short creamy and long grey hairs laterally and dorsally, scattered short black hairs occur in tan and brown areas. Clypeus, chelicerae, maxillae, labium light yellow. Sternum cream with light greyish speckling.

Abdomen oval with pale grey sigillae; entire dorsum covered in pale grey speckled pattern on creamy-white background; long greyish bristles scattered amongst short black hairs (Figure 17). Venter of abdomen cream, with small grey spots in rows that condense to two faint greyish lines in centre. Spinnerets pale grey ventrally, dark grey dorsally. 
Legs yellow with pair of greyish patches or faint stripes on the ventral surface of all femora (retrolateral on legs I and II, retro- and prolateral on legs III and IV).

Proximal receivers of epigyne slightly swollen towards median guide, not separated, right proximal receiver sitting ventral to left proximal receiver. Distal portion of long intermediate canals well separated, lying transversally across anterior portion of spermathecae. Openings of intermediate canals situated at anterior margin of spermathecae (Figures 18, 19). Insemination duct opening on lower lateral border of fossae, over lateral coil of proximal receiver (Figure 19).

\section{Dimensions (mm)}

Holotype $\hat{\sigma}$ (paratype 9 , WAM T125616): total length (excluding chelicerae) 4.22 (5.04). Carapace length 2.07 (2.30). Abdomen length 2.02 (2.82). Leg I: femur 0.94 $(0.84)$, patella $0.44(0.65)$, tibia $0.58(0.55)$, metatarsus 0.68 (0.48), tarsus 0.41 (0.56). Leg II: femur 0.94 (1.03), patella $0.53(0.72)$, tibia $0.41(0.56)$, metatarsus 0.46 (0.43), tarsus 0.43 (0.47). Leg III: femur 1.55 (1.53), patella $0.68(0.72)$, tibia $0.96(0.92)$, metatarsus 0.91 (0.73), tarsus 0.52 (0.60). Leg IV: femur 1.13 (1.18), patella $0.49(0.53)$, tibia $0.62(0.83)$, metatarsus 0.81 (0.93), tarsus $0.54(0.56)$. Legs, relative lengths: III: IV: I: II (III: IV: II: I).

\section{DISTRIBUTION}

Maratus karrie is found in the Warren Bioregion of far south-western Western Australia, ranging from Margaret River to the west, inland and south to Manjimup, Pemberton, Crowea (adjacent to Pemberton) and further south to Mt Roe (north of Walpole) (Figure 30).

\section{REMARKS}

The specimens from Crowea Forest and Manjimup were previously misidentified as $M$. mungaich by Waldock (1995), and the specimens collected by P.J. Darlington from Pemberton and Margaret River were misidentified as 'Maratus sp. A' (i.e. conspecific with M. sarahae) by Hill and Otto (2011) and Otto and Hill (2012a).

\section{ETYMOLOGY}

The specific epithet is derived from the south-western Aboriginal (Nyoongar) word for the eucalypt tree known as Karri (Eucalyptus diversicolor), a dominant tree in the range of this species (Bindon and Chadwick, 1992).

\section{Maratus melindae sp. nov.}

\section{urn:Isid:zoobank.org:act:006D1015-F7A9-4679- 9B1F-EEB8DE7F0773}

\section{Melinda's Peacock Spider}

Figures 20-24, 30

Maratus mungaich Waldock 1995 (in part): 167 (misidentification of specimens from S. of Bluff Knoll).

\section{MATERIAL EXAMINED}

\section{Holotype}

Australia: Western Australia: ô, Mt Trio, Stirling Range National Park, 34²0'59'S, 11806'39'E, vacuuming plants, 6 November 2007, M.L. Moir (WAM T106096).

\section{Paratypes}

Australia: Western Australia: $2 \hat{0}, 12 \mathrm{~km}$ S. of Bluff Knoll, Stirling Range National Park, grid 1.4,

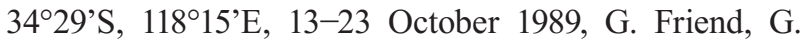
Hall, D. Mitchell (WAM 97/2567-8) [misidentified as $M$. mungaich by Waldock (1995)]; 1 ô, W. of Two Mile Lake, Stirling Range National Park, pitfalls, $34^{\circ} 29^{\prime} \mathrm{S}, 118^{\circ} 15^{\prime} \mathrm{E}$, 10-20 September 1990, G. Friend et al. (WAM T47102).

\section{DIAGNOSIS}

Maratus melindae can be distinguished from all other species in the $M$. mungaich species-group except $M$. caeruleus sp. nov. by the absence of a black 'eye' patch on each abdominal flap (Figure 21); and from $M$. caeruleus sp. nov. by the presence of a medial black abdominal patch dorsally (Figure 20).

\section{DESCRIPTION}

\section{Male (holotype, WAM T106096)}

Cephalothorax black to dark brown with white hairs bordering lateral edges. Dense mat of brown flat hairs covering ocular region. Anterior eyes fringed with creamy-white hairs along dorsal margin; rest of cephalothorax lightly covered with scattered short white hairs and long dark brown bristles on dorsum. Clypeus and chelicerae tan with darker patches on chelicerae. Maxillae, labium light cream. Sternum light grey.

Venter of abdomen pale yellow with greyish smudges forming pale lines; spinnerets black. Dorsal abdominal scute developed as lateral flaps which fold over each other but extendable laterally to exhibit a continuation of dorsal pattern of alternating transverse stripes of redorange (stripes A, B and C) on rose-gold and bright blue background. Stripe A with thin medial black border. Stripe B surrounding central black patch, the latter with two thin black strips extending posteriorly onto posterior border of stripe B; stripe B extending onto flaps and almost reaching lateral edges. Stripe $C$ thin, unbroken dorsally, extending only slightly onto flaps. Centre of dorsal abdomen with a matte black elongate oval patch with small circular light blue spot. Anterior corners of abdomen with red-orange patches and short stiff bright orange bristles; longer black and cream bristles extend from these patches. Stiff long cream bristles project from anterior border of abdomen (Figure 20). No black 'eye' on flaps. Long greyish to cream hairs border abdominal flaps (Figure 21).

Legs covered with dense white hairs interspersed with black bristles. Femora I, II creamy-yellow with greyish-black patches distally merging with retro-lateral patches; femur III creamy-yellow with greyish-black 


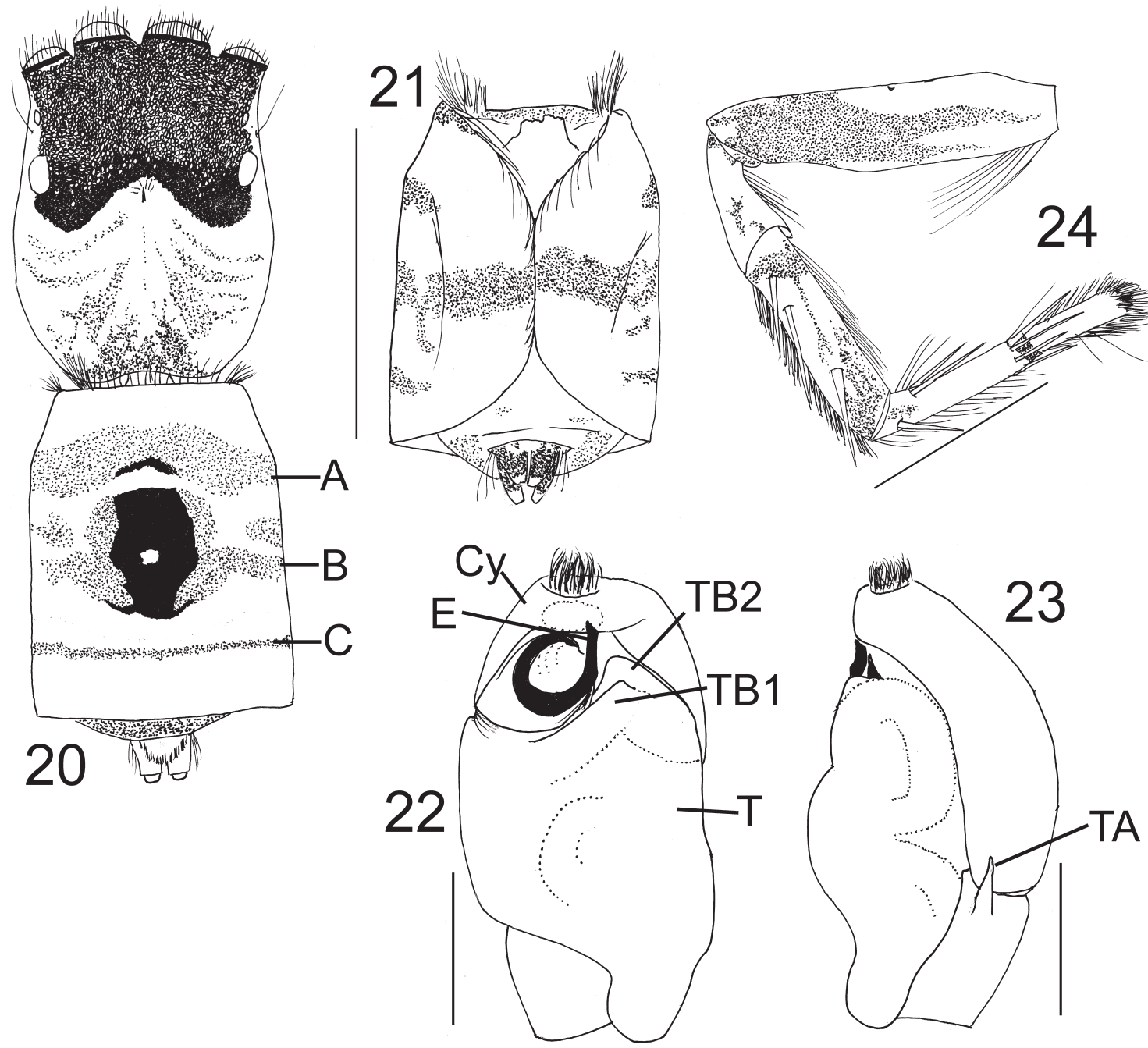

FIGURES 20-24 Maratus melindae sp. nov., male holotype (WAM T106096): 20, cephalothorax and abdomen, dorsal view; 21, abdomen, ventral view (abdominal flaps folded); 22, left pedipalp, ventral view; 23, left pedipalp, retrolateral view; 24, left leg III, retrolateral view. Scale lines $=1 \mathrm{~mm}$ (Figures 20-21, 24), $0.5 \mathrm{~mm}$ (Figures 22-23). A/B/C = red transverse stripes $\mathrm{A}-\mathrm{C} ; \mathrm{Cy}=$ cymbium; $\mathrm{E}=$ embolus; $\mathrm{T}=$ tegulum; TA = tibial apophysis; TB1-2 = tegular bulges 1-2.

patches distally merging with retro-lateral and ventral patches; femur IV creamy-yellow with greyish-black patches distally and small ventral grey patch. Dorsal patellae I, II, IV yellow with dark grey patches ventrally; patella III greyish-yellow. Tibiae and metatarsi I, II, IV greyish-yellow with dark grey bands proximally on each joint; tibia III dark brown; metatarsus III tan. Tarsi I, II, IV greyish-yellow; tarsus III creamy-yellow, with grey patch ventrally at tip. Leg III with brush of black bristles and thick hairs ventrally on patella, tibia and metatarsus; dorsal tibia and metatarsus III with brush of thick black hairs; tarsus III with dense brush of very long white hairs from distal half of dorsal tarsus, extending over tips of claws (Figure 24).

Pedipalp yellowish-grey with scattered greyish patches. Tibial apophysis narrow, straight except for a slight distal curve (Figure 23). Cymbium, dorsal tibia and dorsal patella densely covered with long white hairs, single long creamy hair on dorsal pedipalpal patella only, cream and brown long hairs on tibia, stiff brown bristles on ventral edges of cymbium. Embolus tightly coiled with tip sitting just in from of tip of cymbium; tegulum with two bulges, one behind the other, adjacent to embolus (Figure 22).

\section{Dimensions (mm)}

Holotype $\widehat{\delta}$ : total length (excluding chelicerae) 6.39 . Carapace length 2.97. Abdomen length 3.23. Leg I: femur 1.30 , patella 1.02 , tibia 0.92 , metatarsus 0.70 , tarsus 0.64. Leg II: femur 1.33, patella 0.91, tibia 0.76 , metatarsus 0.63 , tarsus 0.63 . Leg III: femur 2.52, patella 1.20 , tibia 1.50 , metatarsus 1.38 , tarsus 0.84 . Leg IV: femur 1.84 , patella 0.78 , tibia 1.22 , metatarsus 1.29 , tarsus 0.70 . Legs, relative lengths: III: IV: I: II. 


\section{DISTRIBUTION}

This species is known only from within the Stirling Range National Park, from two sites along the southeastern boundary and a single site west of Chester Pass Road along the northern boundary (Figure 30).

\section{REMARKS}

The specimen from Stirling Range National Park, south of Bluff Knoll, was previously misidentified as $M$. mungaich by Waldock (1995).

\section{ETYMOLOGY}

The specific epithet is a patronym in honour of Dr Melinda Moir, in recognition of her continuing work to highlight the unique invertebrate fauna of the southwestern corner of Western Australia.

\section{Maratus caeruleus sp. nov.}

urn:Isid:zoobank.org:act:AABD1643-302A-42D1-98DC7AB6E6E0E689

\section{Blue Peacock Spider}

Figures 25-30

\section{MATERIAL EXAMINED}

\section{Holotype}

Australia: Western Australia: $\widehat{\jmath}$, Recherche Archipelago, Middle Island, 3406'04'S, 12312'08'E, 22 October 2008, on the ground, M.S. Harvey et al. (WAM T95692).
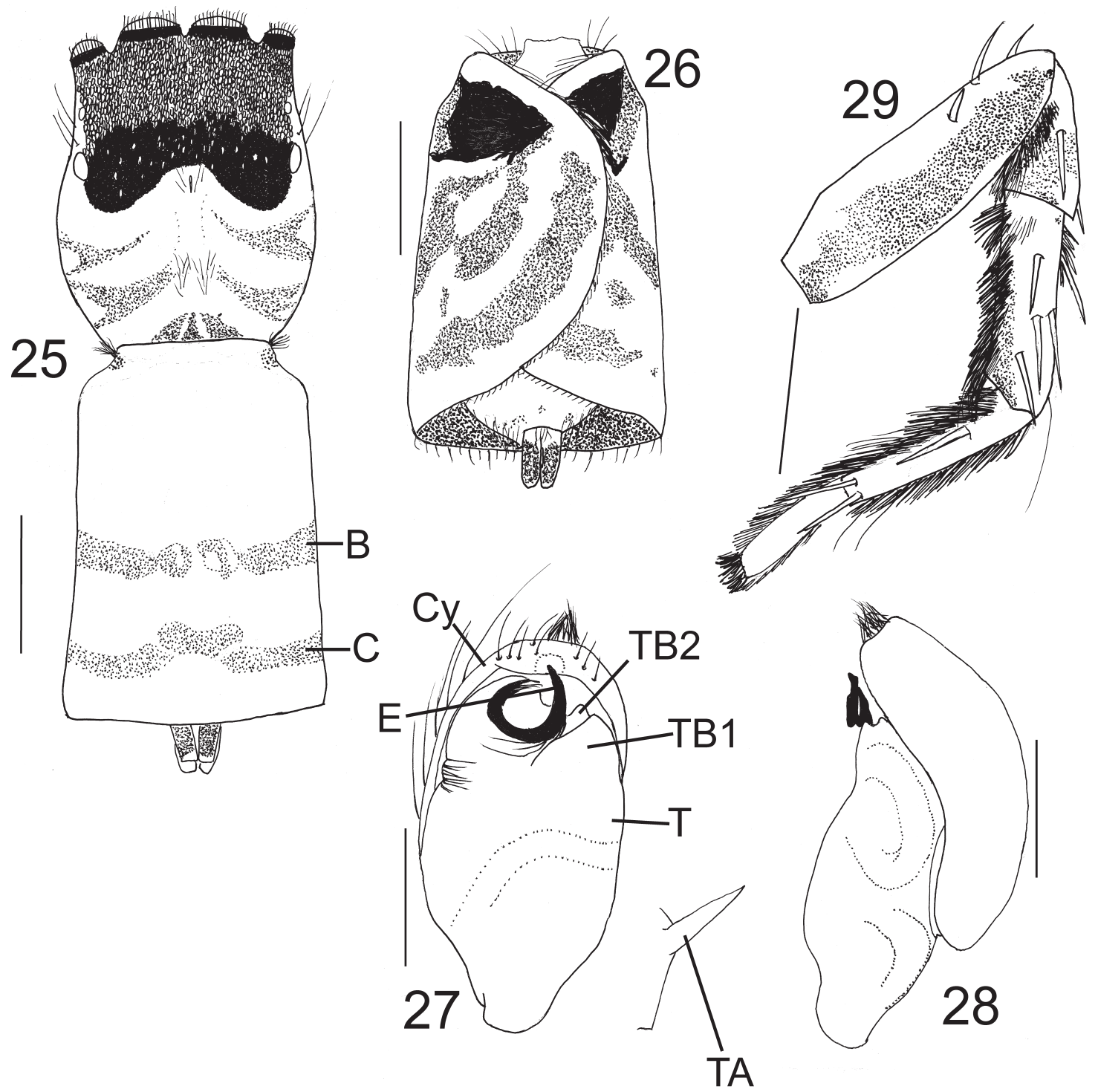

FIGURES 25-29 Maratus caeruleus sp. nov., male holotype (WAM T95692): 25, cephalothorax and abdomen, dorsal view; 26, abdomen, ventral view (abdominal flaps folded); 27 , left pedipalp, ventral view; 28, left pedipalp, retrolateral view; 29, left leg III, retrolateral view. Scale lines $=1 \mathrm{~mm}$ (Figures 25-26, 29), $0.5 \mathrm{~mm}$ (Figures 27-28). B/C = red transverse stripes $B-C ; C y=$ cymbium; $E=$ embolus; $T=$ tegulum; TA = tibial apophysis; TB1-2 = tegular bulges 1-2. 


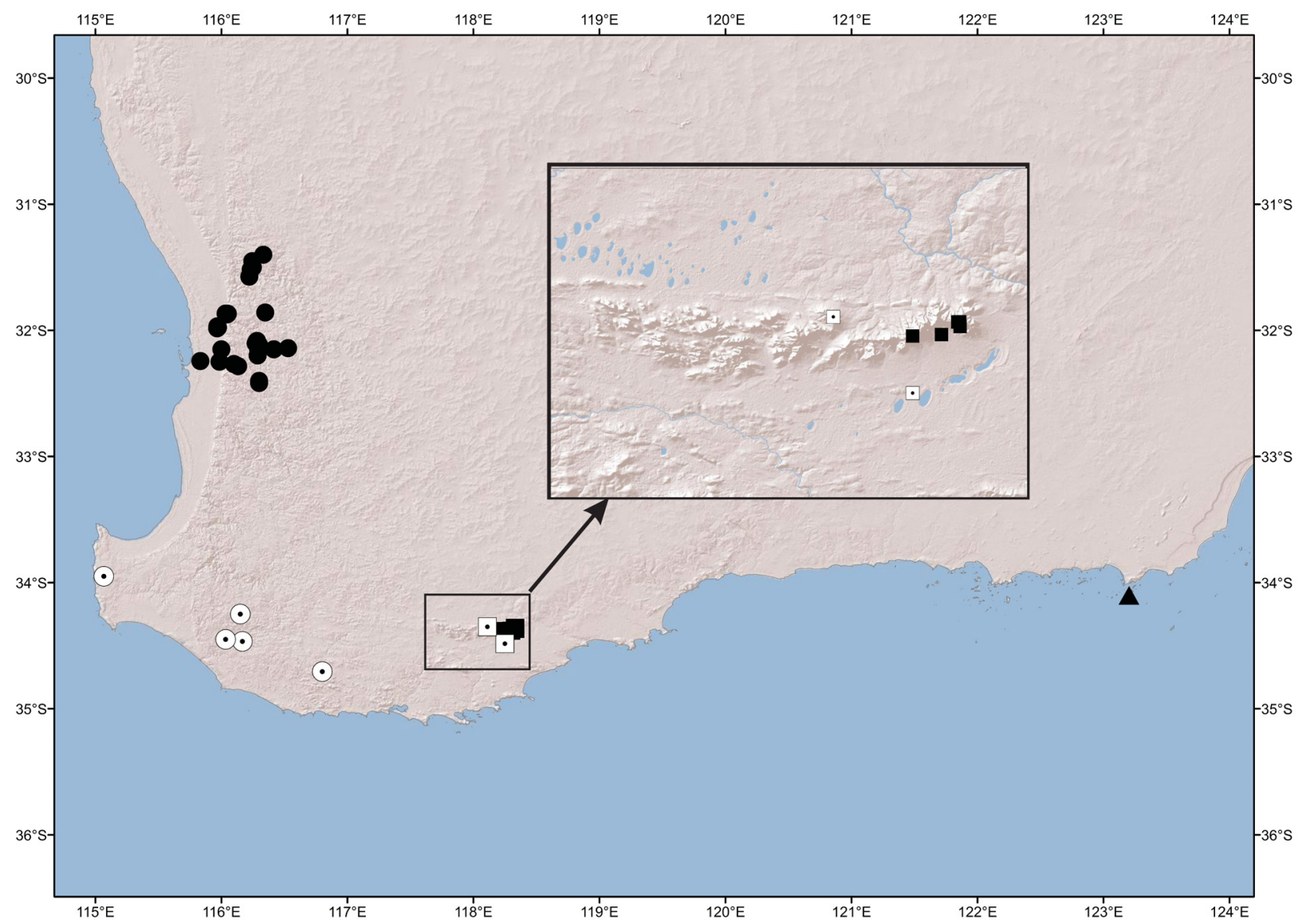

FIGURE $30 \quad$ Map of south-western Western Australia with the collection localities of Maratus mungaich Waldock (solid circles), M. karrie sp. nov. (open circles), M. caeruleus sp. nov. (solid triangle). Inset for collection localities of $M$. sarahae (solid squares) and $M$. melindae (open squares).

\section{Paratype}

Australia: Western Australia: $1 \hat{\partial}$, same data as holotype (WAM T95695).

\section{DIAGNOSIS}

Maratus caeruleus can be distinguished from all other species in the M. mungaich species-group by the absence of a medial black abdominal patch dorsally (Figure 25).

\section{DESCRIPTION}

\section{Male (holotype)}

Cephalothorax black to dark brown with white hairs bordering lateral edges. Dense mat of orange flat hairs covering ocular region. Anterior eyes fringed with bright orange and cream hairs along dorsal margin; rest of cephalothorax lightly covered with scattered short white hairs; dense patch of short white hairs extending posteriorly from fovea on top of cephalothorax, this patch not extending to posterior margin of cephalothorax. Clypeus tan, chelicerae dark brown. Maxillae, labium greyish-yellow. Sternum grey.

Venter of abdomen cream with light grey speckling; spinnerets black. Dorsal abdominal scute developed as lateral flaps which fold over each other but extendable laterally to exhibit a continuation of dorsal pattern. Dorsal abdominal pattern consisting of two narrow transverse stripes of red/orange - stripes $\mathrm{B}$ and $\mathrm{C}-$ on rose-gold and bright blue background. Stripe $\mathrm{C}$ broken medially with a second, slightly anterior thin red strip filling this gap. Stripe A absent, with no central black patches. Anterior corners of abdomen with red-orange patches, and stiff long black bristles projecting from these corners; stiff long black bristles also projecting from anterior border of abdomen (Figure 25). Pattern on lateral flaps consisting of three broad red-orange bands from anterior, centre and postero-lateral edges, curving along border of flap towards distal edge, these bands almost merging at the antero-distal flap edge (Figure 26). Short cream hairs border abdominal flaps (Figure 26).

Legs covered with dense short white hairs interspersed with black bristles, except for leg III which has brush of dark grey and cream bristles on ventral patella, tibia, metatarsus, and dorsal brush of shorter grey bristles on tibia and metatarsus. Dorsal femora I-IV cream, distally 
dark grey, femur III with long white hairs in cream coloured area proximally; patellae I-IV tan; tibiae I-IV brown with dark patches retrolaterally, prolaterally and ventrally; ventral femora I, II and IV cream with dark grey patches proximally and distally. Dark grey patches on ventral femora I, II merge prolaterally with dorsal patches. Metatarsi I, II and IV yellow with greyish patches distally and metatarsus III with greyish band just below proximal joint. Tarsi I, II, IV creamy- yellow; tarsus III cream, with long white hairs extending over claws (Figure 29). Pedipalp light creamyyellow with greyish patch on tibia. Tibial apophysis narrow, straight except for a slight distal curve (Figure 27). Cymbium, dorsal tibia and dorsal patella densely covered with long white hairs, two long black hairs on dorsal pedipalpal tibia and four on cymbium, a few on external ventral side just under tegulum. Embolus tightly coiled with tip sitting just in from tip of cymbium; tegulum with two bulges, one behind the other, next to embolus (Figure 28).

\section{Dimensions (mm)}

Holotype $\hat{\delta}$ : total length (excluding chelicerae) 7.89 . Carapace length 3.97. Abdomen length 4.62. Leg I: femur 1.79, patella 1.13 , tibia 1.03 , metatarsus 0.80 , tarsus 0.49 . Leg II: femur 1.76 , patella 1.11 , tibia 1.01 , metatarsus 0.78 , tarsus 0.69 . Leg III: femur 3.32, patella 1.33, tibia 1.79, metatarsus 1.80 , tarsus 1.00 . Leg IV: femur 2.32, patella 1.14, tibia 1.33, metatarsus 1.65, tarsus 0.91. Legs, relative lengths: III: IV: II: I.

\section{DISTRIBUTION}

This species is known only from Middle Island, situated in the Recherche Archipelago, off the southeastern coast of Western Australia (Figure 30).

\section{REMARKS}

This species is one of the largest thus far known for Maratus, with males over $7 \mathrm{~mm}$ long.

\section{ETYMOLOGY}

The specific epithet is derived from the latin "caeruleus" for sky-blue, in reference to the colour of the male abdomen.

\section{ACKNOWLEDGEMENTS}

I would like to acknowledge support from the Department of Environment and Conservation (formerly Department of Conservation and Land Management) South Coastal Regional office; financial support for surveys by Dr Melinda Moir as part of the South Coast Regional Initiative Planning Team (SCRIPT) and additional financial support from the Western Australian Museum in facilitating the Perth Urban Bushland Survey through Dr Ric How and Dr Mark Harvey. Also, thanks to Laura Liebensperger for the loan of specimens from the Museum of Comparative Zoology, Harvard University. Many thanks to Dr Mark Harvey for facilitating this project and for his comments on earlier drafts of this paper and to Dr Michael Rix who made many valuable comments to this paper.

\section{REFERENCES}

Berry, J.W., Beatty, J.A. and Prószynski, J. (1996). Salticidae of the Pacific Islands. I. Distribution of twelve genera, with descriptions of eighteen new species. Journal of Arachnology 24: 214-153.

Bindon, P. and Chadwick, R. (1992). A Nyoongar wordlist from the south-west of Western Australia. Western Australian Museum: Perth.

Bonnet, P. (1957). Bibliographia Araneorum, vol. 2(3). Douladoure: Toulouse.

Cambridge, O.P.- (1874). On some new genera and species of Araneida. Annals and Magazine of Natural History (4) 14: 178-183, plate 17.

Dunn, R. A. (1957). The peacock spider. Walkabout April 1957: 38-39.

Framenau, V.W. (2007). Volker Framenau's photostream, Salticidae, Maratus. http://www.flickr.com/photos/ australianspiders/4171206705/in/set-72157622842367547 Accessed 21 March 2013.

Girard, M.B., Kasumovic, M.M. and Elias, D.O. (2011). Multi-modal courtship in the peacock spider, Maratus volans (O.P.-Cambridge, 1874). PLoS ONE 6(9): e25390. doi:10.1371/journal.pone.0025390.

Harvey, M.S. (2002). Short-range endemism among the Australian fauna: some examples from non-marine environments. Invertebrate Systematics 16: 555-570.

Hill, D.E. (2009). Euophryine jumping spiders that extend their third legs during courtship (Araneae: Salticidae: Euophryinae: Maratus, Saitis). Peckhamia 74.1: 1-27.

Hill, D.E. (2010). Sunda to Sahul: Trans-Wallacean distribution of recent salticid genera (Araneae: Salticidae). Peckhamia 80.1: $1-60$.

Hill, D.E. and Otto, J.C. (2011). Visual display by male Maratus pavonis (Dunn 1947) and Maratus splendens (Rainbow 1896) (Araneae: Salticidae: Euophryinae). Peckhamia 89.1: $1-41$.

Karsch, F. (1878). Diagnoses Attoidarum aliquot novarum Novae Hollandiae collectionis Musei zoologici Berolinensis. Mitteilungen des Münchener Entomologischen Verein, München 2: 22-32.

Morcombe, M. (1978). Australian Nature Close-up. Lansdowne Press: Dee Why West, N.S.W.

Otto, J.C. and Hill, D.E. (2010). Observations of courtship display by a male Maratus amabilis Karsch 1878 (Araneae: Salticidae). Peckhamia 79.1: 1-16.

Otto, J.C. and Hill, D.E. (2011). An illustrated review of the known peacock spiders of the genus Maratus from Australia, with description of a new species (Araneae: Salticidae: Euophryinae). Peckhamia 96.1: 1-27.

Otto, J.C. and Hill, D.E. (2012a). Description of Darlington's peacock spider (Araneae: Salticidae: Euophryinae: Maratus species A) from the Stirling Range National Park of Western Australia. Peckhamia 101.1: 1-21.

Otto, J.C. and Hill, D.E. (2012b). Notes on Maratus Karsch 1878 and related jumping spiders from Australia, with five new species (Araneae: Salticidae: Euophryinae). Peckhamia 103.1: $1-81$.

Otto, J.C. and Hill, D.E. (2012c). Two new Australian peacock spiders that display inflated and extended spinnerets (Araneae: Salticidae: Euophryinae: Maratus Karsch 1878). 
Peckhamia 104.1: 1-28.

Otto, J.C. and Hill, D.E. (2013). A new peacock spider from Australia displays three 'sapphire gems' on a field of gold (Araneae: Salticidae: Euophryinae: Maratus Karsch 1878). Peckhamia 105.1: 1-8.

Platnick, N.I. (2013). The World Spider Catalog, Version 13.5, http://research.amnh.org/entomology/spiders/catalog/ INTRO1.html. Accessed 4 April 2013.

Prószyński, J. (2005). Catalogue of the Salticidae (Araneae). Version July 2005. http://www.salticidae.org/salticid/ catalog/maratus.htm. Accessed 21 March 2013.

Rix, M.G. and Harvey, M.S. (2012). Australian assassins, part II: a review of the new assassin spider genus Zephyrarchaea (Araneae, Archaeidae) from southern Australia. ZooKeys 191: $1-62$.

Rix, M.G., Roberts, J.D. and Harvey, M.S. (2009). The spider families Synotaxidae and Malkaridae (Arachnida: Araneae: Araneoidea) in Western Australia. Records of the Western Australian Museum 25: 295-304.

Simon, E. (1901). Histoire Naturelle des Araignées, vol. 2: 381-668. Encyclopédie Roret: Paris.

Taylor, C.K. (2011). Revision of the genus Megalopsalis (Arachnida: Opiliones: Phalangioidea) in Australian and New Zealand and implications for phalangioid classification. Zootaxa 2773: 1-65.

Waldock, J. M. (1993). Peacocks of the spider world. Australian Natural History 24 (5): 10-11.

Waldock, J.M. (1995). A new species of Maratus from southwestern Australia (Araneae: Salticidae). Records of the Western Australian Museum, Supplement No. 52: 165-169.

Waldock, J.M. (2008). A new species of Maratus from southwestern Australia (Araneae: Salticidae). Records of the Western Australian Museum 24: 369-373.

Żabka, M. (1987). Salticidae (Araneae) of Oriental, Australian and Pacific Regions, II. Genera Lycidas and Maratus. Annales Zoologici 40: 451-482.

Żabka, M. (1991). Studium taksonomiczno-zoogeograficzne nad Salticidae (Arachnida: Araneae) Australii. Wyzsza Szkola Rolniczo-Pedagogiczna $W$ Siedlcach Rozprawa Naukowa 32: $1-110$.

Zhang, J.-X. and Maddison, W.P. (2013). Molecular phylogeny, divergence times and biogeography of spiders of the subfamily Euophryinae (Araneae: Salticidae). Molecular Phylogenetics and Evolution 68: 81-92.

MANUSCRIPT RECEIVED 9 APRIL 2013; ACCEPTED 21 JUNE 2013. 